\section{ROLAND BARTHES E SEUS PRIMEIROS TOQUES DE DELICADEZA MINIMALISTA. SOBRE O GRAU ZERO DA ESCRITURA'}

Leda Tenório da Motta
Sem fazer a nuança do português entre a escrita e a escritura, a língua francesa designa muitos sentidos à "écriture": a linguagem em sua representação gráfica, a arte de escrever, o documento lavrado em cartório, o conjunto dos livros da Bíblia. Temos aí um único significante e variaçoos de graus da escrita enquanto sacramentada. O que explica que Roland Barthes tenha recorrido a essa palavra - a que não mais deixaria de voltar, o que já nos revela algo sobre sua constância -, quando precisou de uma para distinguir entre a língua comum de que parte todo escritor, uma velha literatura exaurida cujos protocolos já não lhe pareciam mais valer, e uma nova forma, na verdade, quase improvável, a imprimir-se contra a tela de bastidor desse fundo saturado. É essa terceira, definida no negativo, já que em função de sua extrema tensão com a literatura, que Barthes vai chamar "écriture" - e nós, brasileiros, de "escrita" ou "escritura", segundo as preferências tradutórias, oscilantes em nosso mundo editorial -, encarregando-a de representar toda a literatura moderna, em seu movimento suspensivo. "A escritura - lemos logo na abertura de O grau zero da escritura - é um modo de pensar a literatura, não de estendê-la."”

A mais de meio século de distância da obra princeps de Barthes e a trinta anos de seu desaparecimento, que temos, hoje, a dizer desta peça em prosa, que, por sua estranha força, parece seguir sendo um das mais radicais e, bem por isso, intrigantes, da crítica contemporânea? E que dizer deste conceito que ela introduziu, e que se entranhou, desde então, em nosso vocabulário crítico, a "écriture"? E que seria, exatamente, o "degré zéro"?

Em meio a uma surpreendente atual revisão de Barthes - a quem são dedicados colóquios, dossiês, resenhas do último título póstumo, assentamentos biográficos, assentamentos bibliográfios, encômios, balanços que já não terminam mais -, surgem algumas

\footnotetext{
${ }^{1}$ Este ensaio integra o volume em preparação Roland Barthes - O critico se ele ainda existe, a sair pela Editora Perspectiva, de São Paulo.
}

(BARTHES, Roland. Le degré zéro de l'écriture. CEuvres Complètes. Livres, Textes, Entretiens. Nouvelle Édition revue, corrigée et présentée par Éric Marty. Paris: Seuil, 2002: I, 180. Daqui por diante, todas as remissões a Barthes referirão esta edição, salvo menção contrária.) 
(SOLLERS, Philippe. "Sa voix me manque". In: Le Magazine Littéraire, n. 482, Janvier 2009: 82.)

(MARTY, Eric. "Science de la littérature et plaisir du texte". In: BARTHES, Roland. OC: I, 187.) voltas instigantes a estas nomenclaturas fundadoras. De modo geral, a escritura é uma ressignificação do estilo, para Barthes um valor crítico datado, numa situação moderna, em que a palavra "estilo", e tudo aquilo a que o estilo se referia antes, perderam a força, notou Philippe Sollers, num recente número especial da revista Magazine littéraire, num desses dossiês Barthes que agora se abrem. "Tal subscrição da escritura sob o estilo parece justa, até por aclimatá-la à paisagem da literatura clássica, a que Barthes, progressivamente, retornaria. Mas parece-nos também que esse estilo com que Sollers recobre a "écriture" ganha em ser pensado à luz destas outras poucas e incisivas palavras, igualmente recentes, de Éric Marty, o dedicadíssimo editor das obras barthesianas completas, a respeito do primeiro livro: "breve, violento e profanador." Associadas, essas duas falas desses dois barthesianos tão próximos de Barthes nos dão a seguinte solução, talvez condizente com o que ele podia ter em mente quando, emergindo da vida de sanatório, defasado, fora de moda e cheio de ímpeto, vem intrometer-se nos ritos da vida intelectual francesa. "Écriture": ressignificação do estilo como breve, violento e profanador.

Apresente-se o livro. O grau zero da escritura reúne, aumenta e funde uma série de artigos publicados, de 1947 a 1951, numa revista de nome aguerrido - Combat-, bem no espírito de todas aquelas com que Barthes haveria de colaborar, daí por diante, e em que seus futuros livros se antecipariam. Foi ao editor da revista, o crítico francês Maurice Nadeau - que está até hoje em ação e a quem um então desconhecido chamado Roland Barthes deve sua entrada em cena -, que ele enviou, em 1947, um artigo intitulado "O grau zero da escritura". Considerado difícil, mesmo num meio tão intelectualizado, o texto acabou sendo aceito, assim como, na sequência, todos os outros que seriam incorporados ao volume. O título soava estranho, nesses anos de 1950, aos ouvidos não treinados nas nomenclaturas das linguísticas gerais, que ainda não haviam forçado as portas das humanidades. De resto, continuaria sendo estranho até mesmo para os iniciados na virada linguística que prosperaria na França a partir dos anos 60. E o mesmo se pode dizer de tudo aquilo que se segue aos termos do frontispício, até porque, além da provocação oferecida pela carga de palavra inusuais - escritura, grau, grau zero -, o pulso de Barthes é, desde a introdução de seu opúsculo, estranhamente vigoroso, e o texto, muitas vezes, aforismático, como aqui, nesta formu- 
lação que dá bem a medida de seu tom: "A arte clássica não podia sentir-se como uma linguagem, era linguagem".

O conjunto formado pelas colaborações enviadas à Combat - (BARTHES, Roland. OC.: $\mathrm{I}, 172$. está dividido em duas partes, uma primeira sobre a revirada da literatura em "escritura" e uma segunda sobre a revirada da escritura em "grau zero", sob o influxo das narrativas impassíveis do nouveau roman e do apaixonamento inicial de Barthes por Alain Robbe-Grillet. Elas acham-se respectivamente subdivididas em quatro e seis capítulos, todos curtos e fulminantes. O tema mais geral de ambas é a responsabilidade do escritor por sua forma, ou uma "moral da forma", como escreve, inquietantemente Barthes, partindo da ideia preliminar de um desenlace entre o escritor e o mundo burguês, que o obriga a marcar essa separação, a tomar nota do peso de sua linguagem, a inscrever, enfim, esse dilaceramento no que escreve. Já insinuada entre os românticos, desde logo assinalados, através de Chateaubriand, essa ruptura está em pleno curso em Flaubert e Mallarmé. É principalmente diante destes dois grandes, também de saída convocados, que Barthes escreve: "Colocada no cerne da problemática literária, que não começa sem ela, a escritura é [...] essencialmente a moral da forma, é a escolha do domínio [em francês: l'aire] social no seio do qual o escritor decide situar-se na Natureza de sua linguagem."

Por certo, nem tudo aí cai do céu. A "responsabilidade", a "moral" da forma e - principalmente - o "domínio social" são referências em que os comentadores desse primeiro livro concordam em reconhecer a presença de Sartre. O que não surpreende, dada a proeminência do maître à penser que é Sartre no momento em que Barthes começa a escrever. Quem quer que queira - então refazer a trajetória do primeiro Barthes, deve acusar, de saída, que há ressonâncias flagrantes entre Le degré zéro de l'écriture e Qu'est-ce que la littérature?, obra de um Sartre crítico literário que, cinco anos antes, em 1948, também faz tabula rasa das definiçōes assentadas da literatura.

Inegavelmente, é sartriana essa dimensão do engajamento assinalada pela "moral da forma", bem como essa percepção das formas da arte como históricas e do artista como aquele que não pode não se saber histórico. Assim como é sartriano este alerta de Barthes, que depois seria o leitmotiv de Mitologias, volume eternamente às voltas com a nossa alienação no mito, que nada mais é para Barthes que a supressão da História: "é ali onde a História é recusada que 
ela age mais claramente." ${ }^{\text {E }}$ assim como é sartriano - em suma ver a literatura como um gesto, e um gesto que pede explicação, como o assume Sartre: "Já que os críticos me condenam em nome da literatura, sem nunca me dizer o que entendem por literatura, a melhor resposta a lhes dar é examinar a arte de escrever, sem pre-

(SARTRE, Jean-Paul. Qu'est-ce que la littérature?. Paris: Gallimard, Col. Idées, 1948: 10.)

· (DOUBROVSKI, Serge, Pourquoi la nouvelle critique? - Critique et objectivité. Paris: Mercure de France, 1966: 2.)

" (MARTY, Eric. "Présentation". In : BARTHES, Roland. $O C: 1,15$. julgamentos. O que é escrever? Por que se escreve? Para quem? Parece, com efeito, que ninguém nunca se perguntou isso". Assinalando as muitas coincidências entre esses dois pequenos e graves livros, tão próximos no tempo, Serge Doubrovski afirma, em seu Pourquoi la nouvelle critique?, que ambos são "etapas capitais dessas revisões periódicas que faz nossa época pouco estável, onde elas entram como julgamento do homem e da sociedade". * Por seu turno, cuidando da rede de influências ativas sobre Barthes nos anos 1942-1961, em seu estabelecimento das Euvres Complètes, Éric Marty põe Sartre nessa rede, a que depois incorporaria Saussure, explicando que "o primeiro tomo das obras barthesianas completas tem por intertextos Sartre, Marx, Brecht”.

Basta porém nos aprofundarmos nos meandros de $O$ grau zero da escritura para que diferenças notáveis, que já imprimem a marca barthesiana, nos saltem à vista, permitindo-nos ainda dizer que tudo une e separa Barthes de Sartre. De fato, se é verdade, de um lado, que essa obra estremecedora é movida pela mesma paixão do engajamento, note-se que o engajamento barthesiano é, muito paradoxalmente, antissocial. Já que a sociedade que Barthes tem em vista não é aquela sobre a qual a escritura deve incidir, mas aquela que a escritura deve repudiar completamente, não mais atuando sobre ela, mas antes, desativando aquilo mesmo que permitiria alcançá-la: a comunicação entre o escritor e o leitor, mesmo ideal. Escrever, nesta acepção, é quebrar todo o circuito social da obra. A escritura tal como Barthes a entende não se situa frente ao mundo, mas frente à própria linguagem, e não o faz sem corrompê-la em seu valor de meio de contato e de compreensão. Não fosse assim, ainda estaria, para ele, no ritual das letras ou no "decorativo" do estilo. ${ }^{2}$

O mesmo vale para a influência de Marx, também muito apontada, até porque inseparável da de Sartre. O marxismo, como

\footnotetext{
${ }^{2}$ Barthes escreve: "A poesia clássica não era sentida senão como uma variação ornamental da Prosa, como o fruto de uma arte (quer dizer, de uma técnica), nunca como uma linguagem diferente ou como o produto de uma sensibilidade particular. Toda a poesia nada mais é, então, que uma equação decorativa, alusiva ou carregada, de uma prosa virtual que jaz em essência e em potência em qualquer expressão". (Ibidem.) Grifo meu.
} 
se sabe, foi uma paixão intelectual do século XX, e Barthes a representa plenamente, no abatimento do pós-segunda guerra, ainda que recuse o "dogmatismo moscovita", ou por isso mesmo. Louis-Jean Calvet nos diz que, ao deixar o sanatório de Leysin, na Suíça, onde fora internado, em 1945, para um novo tratamento da tuberculose, desta feita fora da França, ele sai "quase curado e marxista". . Assim pois, antes de ser sartriana, ou junto com ser sartriana, a acusação do peso da História é marxista. Assim como é marxista a formulação "escritura burguesa" a que $O$ Grau zero da escritura volta sem cessar. E assim como é marxista esta afirmação que encontramos na seção de $O$ grau zero da escritura intitulada "Escritura e revolução": "a expressividade é um mito, ela nada mais é que a convenção da expressividade", pois isso quebra a corrente entre o escritor e o leitor que a forma expressiva quer fazer passar. ${ }^{*} \mathrm{E}$ assim como, pouco mais adiante, será marxista toda a crítica ideológica desenvolvida em Mitologias contra uma França burguesa e pequeno-burguesa que Barthes detesta e que o leva a traçar todos aqueles seus formidáveis quadros da vida cotidiana na era da publicidade e do marketing que, invariavelmente, terminam com reflexões no tom deste aforismo delicioso: "A euforia do OMO não nos deve fazer esquecer de que existe um plano em que o sabão em pó é o seguinte: o plano do truste anglo-holandês Unilever". 'De resto, quando escreve $O$ grau zero da escritura, ele já vive sob o efeito do teatro de Brecht, que havia descoberto, em 1955, quando da vinda do Berliner Ensemble a Paris, para uma encenação de $O$ círculo de giz caucasiano. E sabe-se quanto Brecht o politiza, não só pelas pistas que nos dá sua constante menção à "histeria", que, como mau teatro, é o contrário do distanciamento crítico brechtiano, mas porque ele é o primeiro a dizê-lo, quando escreve sobre: "seu teatro tem toda a densidade de uma criação mas essa criação funda-se sobre uma crítica poderosa da sociedade, sua arte confunde-se sem nenhuma concessão com a mais alta consciência política”. No conjunto da obra barthesiana, a própria formulação "a língua é fascista" - que interviria escandalosamente na aula inaugural no Collège de France, em 1977 -, tem sido associada a uma "mística revolucionária" que é caudatária do marxismo.

Ocorre que também o marxismo é aqui transversal. De fato, temos motivos para pensar que, em 1953, Barthes já é aquele marxista dubitativo e excêntrico que diz, em Ensaios críticos, que a ortodoxia marxista torna-se estéril ao propor uma explicação me-
(BARTHES, Roland. "Scandale du marxisme". OC: I, 125.)

- (CALVET, Louis-Jean. Roland Barthes - Uma biografia. Tradução de Maria Angela Villela da Costa. São Paulo: Siciliano, 1993: 85.)

- (BARTHES, Roland. Le degré zéro de l'écriture. OC: I, 212.)

- (BARTHES, Roland. Mythologies. OC: I, 700.)

-(BARTHES, Roland. "Pourquoi Brecht?". OC: 1, 576.)

- (Cf. MERLIN-KAJMAN, Hélène. La langue est-elle fasciste?. Langue, pouvoir, enseignement. Paris: Seuil, 2003: 45.) 
(BARTHES, Roland. Essais critiques. OC: II, 502.)

(BARTHES, Roland. Entrevista inédita a Jean-José Marchand e Dominique Rabourdin. In: Le Magazine Littéraire, n. 482, Janvier 2009.)

( (Ibidem: 68.)

* (KRISTEVA, Julia. Sens et nons-sens de la revolte. Paris: Pouvoirs et limites de la psychanalyse. Vol. I. Paris: Fayard, 1996: 395.) cânica das obras pelas fontes e promulgar mais palavras de ordem que critérios, e que os melhores críticos são aqueles que, como Lucien Goldmann, estão às voltas com o mundo social, mas sem que se tenham instalado "num centro declarado Marx". "A propósito, temos a sorte de poder ouvi-lo não só voltar a essa questão mas referi-la a $O$ grau zero da escritura, numa entrevista inédita, gravada em 1970, em sua casa, na Rua Servandoni, e só publicada recentemente, em 2009, na mesma Magazine littéraire. Nessa conversa, ele se vê por cima dos próprios ombros e se explica a respeito de Marx e Sartre:

O sartrismo e o marxismo, que tão profundamente pensavam o engajamento político, o engajamento ideológico e, vamos dizer assim, o engajamento das ideias ou das condutas, nunca se preocuparam com aquilo que podemos chamar o engajamento das formas, a responsabilidade das formas, a responsabilidade da linguagem. No fundo, O grau zero da escritura, com meios intelectuais frágeis, bem entendido, queria preencher essa lacuna e propor uma primeira reflexão sobre o que se poderia chamar a responsabilidade da forma, a responsabilidade da linguagem.

Nessa oportunidade, temos também a sorte de ouvi-lo confirmar suas primeiras e últimas paixões: "se eu tivesse hoje que apresentar de novo $O$ grau zero da escritura, guardaria essencialmente a mesma motivação, a mesma pulsão, o mesmo movimento, encaminharia a mesma ética, se me permitem dizê-lo". Sorte é também poder ouvir Kristeva - que também vê as coisas de perto e de dentro, sendo outra companheira de estrada de Barthes - retomar o ponto, num livro dos anos 1990: "Na verdade, o que tentávamos - principalmente Roland Barthes - era, não aderir à doxa marxista, mas nos avizinhar dos movimentos de esquerda - Brecht, gauche, maoísmo -, tomando-os como modos críticos de remover burocracia e buscar uma renovação da generosidade socialista." ${ }^{\text {* }}$

É por ficar entre o engajamento e a forma que O grau zero da escritura descreve essa sua curva ascendente da tomada de consciência da linguagem pelos escritores. Arco de acontecimentos em que só entram episódios cruciais, que aí se desdobram em dois tempos fortes. Num primeiro tempo, estamos no "assassinato" da literatura por Flaubert (na prosa) e Mallarmé (na poesia), dois "écrivains" que, exemplarmente, a tomam como coisa em si. Num segundo tempo, que é a curva do "degré zéro", propriamente dito, num quadro de herdeiros desse meurtre que engloba, principalmente, Al- 
bert Camus, escritor renomado do período, que Barthes começa por admirar, mas de que logo acusará o vezo piedoso; Raymond Queneau, vanguardista saído da diáspora surrealista, em cujo $Z a$ zie no metrô vê consumar-se o papel do escritor, que é combater a literatura; o hoje esquecido Jean Cayrol, que emerge no bojo da revista de Philippe Sollers e que é um dos raros poetas a se insinuarem nos escritos barthesianos; e Maurice Blanchot, enquanto romancista órfico ou escritor sem literatura. A este rol seria, logo mais, acrescentado, em artigos dos mesmos anos 1950, só reunidos em Ensaios críticos, em 1964, o nome de Alain Robbe-Grillet, um destruidor do romance que está então despontando, em cujos relatos a frio sobre objetos inanimados Barthes localiza outra literatura da pura constatação, semelhante à de $O$ estrangeiro. E vale notar ainda que, mais tarde, Barthes reconheceria que ficaram faltando, em sua relação dramática, Antonin Artaud, Georges Bataille e Francis Ponge, autores do instigante cânone francês revisto pelo grupo Tel Quel, ${ }^{3}$ a que ele mesmo passa a pertencer. Por ora, reserva-se à primeira formação a "écriture", e à segunda, todas estas apelações sinônimas: o "grau zero da escritura", "escritura branca" e "escritura neutra". Barthes as confunde todas, definindo-as juntas: "A escritura branca, a de Camus, a de Blanchot, a de Cayrol, por exemplo, ou a escritura falada de Raymond Queneau [são] o último episódio de uma Paixão da escritura, que acompanha passo a passo o dilaceramento da consciência burguesa." ${ }^{*}$ Trata-se do que resta à literatura, depois de sua destruição final.

No trânsito da escritura para o grau zero, o que esse movimento ascensional - se cabe a palavra - encerra é uma progressiva reificação da linguagem, assim resumida: “Todo o século XIX viu avançar um fenômeno dramático de concreção. Em Chateaubriand, isso não é mais que um pequeno preço a pagar, o peso leve de uma euforia da linguagem, uma espécie de narcisismo em que a escritura mal se separa de sua função instrumental para reparar em si mesma. Flaubert - para só ficarmos aqui nos momentos típicos desse processo - constituiu definitivamente a literatura em objeto, pela força de um valor-trabalho: a forma torna-se assim o termo de uma "fabricação", como uma cerâmica ou uma joia [...].

\footnotetext{
3 "Essas 'exclusões' eram ignorância: eu não conhecia nem Artaud, nem Bataille, nem Ponge." Cf. BARTHES, Roland. "Réponses”. OC: III, 1028. Trata-se de uma entrevista originalmente publicada num dossiê Barthes da Revista Tel Quel, número 47, outono de 1971.
}

•(BARTHES, Roland. "Zazie et La littérature". Essais critiques. OC: II, 382.)

"(Ibidem: 173.) 
• (Ibidem.)

" (BARTHES, Roland. "La mort de I'auteur". OC: III, 40.)

* (BARTHES, Roland. Le degré zéro de l'écriture. OC: I, 40.)

* (BARTHES, Roland. La mort de I'auteur. OC: III, 41-42. Grifo do autor.)

(SARTRE, Jean-Paul. op. cit.:105.)

" Roland Barthes. Le dégré zéro de l'écriture. OC: I, 217.)
Mallarmé, por fim, coroou essa construção da Literatura-Objeto com o ato último de todas as objetivaçôes, o assassinato: sabemos que todo o esforço de Mallarmé dirigiu-se a uma destruição da linguagem, de que a literatura seria, de algum modo, o cadáver". Barthes o dirá de novo, depois, em 1968, em "A morte do autor": "toda a poética de Mallarmé consiste em suprimir o autor em benefício da escritura".

É na "consciência infeliz" que ela toma lugar, pela "alternativa terrível" que é oferecida ao escritor: ou lançar mão de uma linguagem investida por valores ideológicos de classe que ele mesmo contesta ou recusar a linguagem. Escreve Barthes:

A burguesia produziu uma escritura única que não podia ser dilacerada porque a consciência não o era. Mas no momento em que $o$ escritor deixou de ser uma testemunha do universal para tornar-se uma consciência infeliz (por volta de 1850), seu primeiro gesto foi o de escolher o engajamento de sua forma, seja assumindo, seja recusando a literatura e seu passado...

Como se sabe, este será ainda o ponto, em $A$ morte do autor, em que o escritor moderno é visto, justamente, como aquele que fez a segunda opção. Outro exemplo é o de Proust, cujo narrador "não é o que viu ou sentiu ou, mesmo, escreveu, mas o que vai escrever". O que o mostra desapossado de seus meios."

Abra-se aqui espaço para notar que a consciência infeliz também é rigorosamente sartreana. Foi Sartre quem escreveu, em $O$ que é a literatura?, que "o escritor dá à sociedade uma consciência infeliz porque está em perpétuo antagonismo com as forças conservadoras que mantêm o equilíbrio que ele tende a romper.

De resto, lemos aí algo que também diríamos saído da forja barthesiana, não fosse a forja barthesiana sair daí: "o poeta é um homem que se recusa utilizar a linguagem". ${ }^{4}$

Mas o "assassinato" que dela decorre é de Maurice Blanchot. Como reconhece o próprio Barthes: "Sabemos o que a hipótese de um Mallarmé assassino da linguagem deve a Blanchot". Embora, no momento em que sai $O$ grau zero da escritura, Blanchot não tivesse ainda publicado aquela parte de sua obra que viria a ser a mais importante - L'espace littéraire (1955) e Le livre à venir (1959)

\footnotetext{
${ }^{4}$ op. cit., p. 17. Daí Sartre comparar a emoção poética a uma pincelada de Tintoreto, assim considerada: "Esse rasgo amarelo no céu acima do Gólgota, Tintoreto não o escolheu para significar a angústia, nem tampouco para provocá-la; ela é angústia e céu, ao mesmo tempo. Não céu de angústia ou céu angustiado, angústia feita coisa...”.
} 
-, podemos pensar que a "écriture" é o "espaço literário" de Blanchot, neste sentido que, para este Blanchot, escrever é uma prática essencialmente solitária e, desde Mallarmé, um gesto extremo, reduzido "à expressão mais rasa, ao que parece ser o simples gesto do artesão".

Há muito também de Blanchot em Barthes, como igualmente se admite. Ronda esta outra revisão do sentido da literatura a mesma articulação entre ela e a morte. Assim, não é de surpreender que, em Ensaios críticos, Blanchot esteja ao lado dos melhores representantes da crítica feita em língua francesa - numa relação que enfileira Sartre, Gaston Bachelard, Lucien Goldmann, Georges Poulet, Jean Starobinski, René Girard e Jean-Pierre Richard na separação de águas que faz Barthes, então em pleno choque com a Sorbonne, num ensaio chamado "As duas críticas", entre a crítica "da interpretação", que é a dos leitores da escritura, e a "crítica universitária", que é a dos "positivistas", que veem a literatura como o produto de uma causa externa.*

Figura tutelar para todo o grupo Tel Quel - como nota Christophe Bident ${ }^{*}-$, Blanchot impõe-se tanto mais a Barthes quanto ambos chegam praticamente juntos ao desaparecimento do autor - e não do homem, como se empenha em sublinhar Éric Marty, defendendo um Barthes mais estruturalista que os estruturalistas, por abster-se do homem e ater-se ao sujeito do texto ${ }^{5}-$, e o fazem apelando para a mesma palavra, aliás, prometida a um futuro em Barthes: o neutro. De fato, em Le livre à venir, num capítulo, por coincidência, intitulado "A palavra neutra", é Blanchot quem faz ressoar Barthes: "Fazem-nos estranhas perguntas, por exemplo: quais

${ }^{5}$ Ele escreve: "Podemos dizer que ele foi um dos raros estruturalistas rigorosos, tendo escapado à tentação de fazer do estruturalismo uma antifilosofia, como Althusser, Lacan ou Foucault. Não sendo filósofo e não se sentindo minimamente em dívida com a filosofia, Barthes não teve que justificar-se perante os filósofos e a filosofia. Evitou assim a escabrosa aventura do anti-humanismo, os planos ambiciosos que visavam desconstruir a metafísica e outros projetos grandiosos. O estruturalismo, a seus olhos, não era uma filosofia, e não podia ser uma antifilosofia. Tudo para ele acontecia à margem da filosofia, e sem consequências para ela. Nenhuma raiva antissartriana o compelia; não havia nenhum desprezo de sua parte pela fenomenologia reduzida a uma filosofia do existir. [...] Lévi-Strauss deu-se por finalidade dissolver o homem, Foucault tematizou sobre a morte do homem [...]. Barthes contentou-se em falar na 'morte do autor', o que era mais prudente e mais estrutural, pois significava aceitar não ultrapassar os limites mesmo da estrutura...”. Cf. $O C$, II:19.
- (BLANCHOT, Maurice Blanchot. Le livre à venir. Paris : Gallimard, Col. Idées : 33 .)

- (BARTHES, Roland. Essais critiques. OC: II, 496.)

- (BIDENT, Christophe. Maurice Blanchot partenaire invisible. Seyssel: Champ Vallon, 1998: 459.) 
- (BLANCHOT, Maurice Blanchot. Le livre à venir. op. cit.: 285.)

(BARTHES. Roland. Le Neutre. Cours au Collège de France 1977-1978. Texte établi, annoté et présenté par Thomas Clerc. Paris: Seuil/ IMEC, 2002: 138.)

(Ibidem: 48.)

"(BIDENT, Christophe. "R/M 1953". In: QUEIROZ, André; MORAES, Fabiana de; CRUZ, Nina Velasco e (org.). Barthes/Blanchot. Um encontro possível?. Rio de Janeiro: 7 Letras, 2007: 98. )

• (MARTY, Éric. "Le neutre barthesien, I'abondance de sens". In: Magazine littéraire. op. cit.: 62.) são as tendências da literatura atual, ou ainda: para onde vai a literatura. Pergunta curiosa, sim, mas o mais curioso é que, se houver resposta, a resposta é fácil: a literatura vai na direção de si mesma, na direção de sua essência que é o desaparecimento" . É bem por isso que vemos Blanchot assomar, constantemente, no volume $O$ Neutro. Veja-se a transcrição das notas para a aula do dia $1^{\circ}$ de abril de 1978, em que o neutro blanchotiano é evocado a propósito da embriaguez baudelairiana:

Opacidade na transparência. Blanchot apontou bem o paradoxo daquilo que chama o Neutro e eu chamo a consciência-droga: $\mathrm{O}$ Neutro nos remeteria à transparência, de cujo estatuto ambíguo e não-inocente é a marca. Haveria uma opacidade da transparência. Paradoxo que transcrevo desta forma: o sujeito (que eu sou) é como uma partitura, cada parte é independente, clara, viva, entoada e ouvida vivamente; mas não há em mim, por trás de mim, nenhum eu para ler o conjunto, verticalmente, harmoniosamente. Hiperconscência, Neutro: eu sou claro para mim mesmo mas sem verdade, uma língua clara (de modo nenhum hermética, absconsa), mas sem referente.

Aliás, ao reivindicar, aí mesmo, o ceticismo radical de Pyrron, Barthes o põe na linha do neutro de Blanchot, permitindo-se inverter as mãos de direção e dizer: "Pyrron criou alguma coisa: não digo o que porque não foi bem uma filosofia, nem um sistema; eu diria: criou o Neutro, como se tivesse lido Blanchot.”*

Também neste caso, tudo une e separa Barthes deste seu outro interlocutor privilegiado. Como também pensam muitos, a começar por Bident, que, sendo o biógrafo de Blanchot, com todo seu conhecimento de causa, escreve: "Blanchot foi o homem do absoluto, Barthes o do plural”. . O que Éric Marty explica melhor, concordando com Bident: o neutro de Blanchot deseja o indizível, o desconhecido, o interminável, numa palavra, algum absoluto, é aberto e luminoso. ${ }^{*}$ Ele quer dizer, assim, que o de Barthes rejeita qualquer flerte com a transcendência. Essas diferenças na cumplicidade fazem com que Blanchot, de hábito tão reservado, reaja à impetuosa figura fora de moda que lançou $O$ grau zero da escritu$r a$, como já reagira a $O$ que é a literatura? de Sartre, vindo a público notar que o livrinho de Barthes era uma raridade. ${ }^{6}$

\footnotetext{
${ }^{6}$ Leia-se Leyla Perrone Moisés a respeito: "Cinco anos depois do ensaio de Sartre,em 1953, Roland Barthes publicou O grau zero da escritura, que foi logo apontado por Blanchot como "um dos raros livros em que se inscreve o futuro das letras". Cf. MOISÉS, Leyla Perrone. "Sartre, Barthes e Blanchot: a literatura
} 
Fadado a ganhar um peso enorme no último Barthes - quando vai destramar todas as insinuaçōes do mito, da histeria, da arrogância, com toques de delicadeza poética minimalista, como sabe quem leu o volume saído dos seminários que lhe são consagrados, entre 1977 e 1978 -, o Neutro - que progressivamente se instala nos escritos barthesianos com letra maiúscula - já é aqui, para estas escrituras retardatárias e sobreviventes de que trata $O$ grau zero da escritura, a condição de uma existência ao mesmo tempo dentro e fora da linguagem, ou dentro da linguagem mas fora da coerção da linguagem, ou comportando-se como se estivesse fora dessa coerção. Sinônimo de "grau zero", ele é a "écriture blanche", a escritura no extremo de sua fragilidade e na sua última contradição, ou na sua existência pós-mallarmeana. Trata-se de uma terceira dimensão da forma que o corte saussuriano, aliás, não prevê, já que tudo em Saussure é não apenas dicotômico porém produtivo em termos de significação.

Mas que seria isto: uma escritura no grau zero?

Acrescentando-se à bateria dos binômios saussurianos - signo e referente, significante e significado, língua e discurso, enunciado e enunciação - a nomenclatura e a ideia do "grau zero", que estão por trás do neutro barthesiano, procedem de uma linha heterodoxa das linguísticas gerais ativas sobre o linguistic turn francês, nos anos 1960. A saber, a linha dos trabalhos de um representante do Círculo Linguístico de Copenhague chamado Viggo Brondal, que conhecemos bem menos que Hjelmslev, o introdutor da denotação/conotação. A julgar pela recorrência do Neutro em Barthes, pensamos que Brondal pode ser visto, hoje, como um de seus primeiros e mais importantes guias. Desde a primeira hora, é ele quem o leva a considerar um terceiro termo possível no jogo paradigmático da língua, mecanismo que vem se chocar com o sistema de permutaçóes do tabuleiro de xadrez de Saussure. Segundo essa teoria, que não aprendemos a recepcionar, malgrado sua inflexão sobre a obra de Barthes, há na língua certas ocorrências em que esse sistema se enfraquece. $\mathrm{Na}$ descrição de Brondal, uma oposição significante é desativada, por exemplo, quando, entre o subjuntivo e o imperativo, interpõe-se o indicativo, como uma forma não

em declínio". In: QUEIROZ, André; MORAES, Fabiana de; CRUZ, Nina Velasco e (org.). Barthes/Blanchot. Um encontro possivel?. Rio de Janeiro: 7 Letras, 2007:18-19. 
(KRISTEVA, Julia. Étrangers à nous mêmes. Paris: Gallimard, Col. Folio-Essais, 1988: 43.)

(BARTHES, Roland. Essais critiques. OC: 1, 294) modal. É assim que, para Barthes, a escritura neutra será aquela puramente indicativa.

À época de $O$ grau zero da escritura, ilustração de uma língua literária não mais que indicativa pode ser a de Albert Camus, que vinha, então, de publicar L'étranger, sua única obra suscetível de interessar Barthes, logo depois, disposto a acusar $A$ Peste de abstraçōes cheias de sugestōes humanitárias e metáforas da Ocupação. Nesse momento - então -, o "degré zéro" recobre, exatamente, isto: "Mamãe morreu hoje, ou talvez ontem, não sei. Recebi um telegrama do asilo: Falecimento mãe. Enterro amanhã. Saudações.” Mais adiante, ainda melhor ilustração poderá ser qualquer momento de Alain Robbe-Grillet. Com efeito, O grau zero da escritura e Les Gommes são do mesmo ano: 1953. Isso explica que não haja menção a este vanguardista tardio no livro de estreia de Barthes. $\mathrm{O}$ fato é que, como havia feito com Camus, Barthes reagirá de imediato a este outro escritor emergente, que também lhe parece suficientemente insólito para poder seguir representando a morte da literatura. Data de 1954 o primeiro dos muitos artigos que lhe dedica desde que o descobre, um texto de título e sentido só bizarro para os não introduzidos à insistente utopia do grau zero ou do neutro: "A literatura objetiva". Ele seria depois inserido em Ensaios críticos, reunião de textos imediatamente posterior, que nos deixa continuar a ver o que se passa anteriormente com Barthes. Aí, quatro capítulos giram explicitamente em torno de Robbe-Grillet.

Relembrá-los é continuar a apresentar a escritura do zero grau, agora na prática. No primeiro deles, Barthes, que ainda não havia parado para pensar no "efeito de real", o que só viria a acontecer em 1968, mas já se perguntava sobre o encontro dos objetos e sua expressão, compara o realismo de Les gommes com o realismo tradicional. Nota que, no caso deste último, o tratamento é tendencioso, que a minúcia da descrição procede aí de um julgamento implícito, ainda que escondido, que acrescenta qualidades ao que está sendo observado. "Os objetos têm formas, odores, propriedades táteis, fervilham de significação”. * É a lógica do enquadramento, a lógica do meio, tal como ele a vê funcionando ainda no Flaubert de Madame Bovary, que até então trabalha com uma certa lei do romance, ou com uma certa retórica da verossimilhança. Ora, é contra esse volume de informações que vem chocar-se o novo-romancista. Aqui, nesta outra paisagem, o objeto não é "psicológico", é "cabeçudo" (entêté). Apenas está deposi- 
tado diante de nós, ou apenas "está”, como escreve Barthes. "Toda a arte do autor está em dotá-lo desse 'estar' (être là), removendo-lhe o "ser algo" (être quelque chose). "Este é um mundo que o fascina por ser sem coração. Coração carrega "o mito da intimidade substancial", como diria o mestre Gaston Bachelard. 'Ao passo que o grau zero é rasante.

O segundo introduz um novo apelativo possível para o grau zero: "literatura literal". Lemos aí que os romances de Robbe-Grillet nos educam com firmeza para que nos mantenhamos "no patamar do objeto", e que seu desígnio é dotar, por fim, os objetos de um privilégio narrativo antes concedido unicamente às relações humanas. ${ }^{*} \mathrm{O}$ terceiro brinda o escritor com o epíteto-homenagem de "coisista" (chosiste), o que significa que, ao contrário do que acontece em Butor, por exemplo, cujas personagens se deixam descrever pelos objetos, os objetos de Robbe-Grillet expulsam o homem. ${ }^{*} \mathrm{O}$ último, já é um balanço e vemos surgir aí uma certa ponta de decepção do crítico em relação ao escritor que praticamente lançou. Decepção que, no entretanto, nada tem a ver com o desencanto em relação a Camus (logo transformado em ideólogo), muito maior e de molde a esfriar as relações entre ambos, como mostra a troca de cartas entre Barthes e Camus que está hoje inserida no primeiro dos cinco volumes das oeuvres barthesianas.

Para arrematar estas breves ponderações, sublinhe-se que, um quarto de século depois, a "morte do sentido", pela qual tudo havia começado, ainda lá estaria, fechando o círculo, nas aulas sobre $O$ Neutro. Nesse quase apagar das luzes, não se fala mais de nenhum dos novos autores evocados em 1953. Para a abertura das conferências, em 18 de fevereiro de 1978, Barthes anotara isto:

Dou do Neutro uma definição que segue sendo estrutural. Quero dizer com isso que, para mim, o Neutro não remete a impressões de "modorra" (grisaille), de neutralidade, de indiferença. O Neutro - meu Neutro - pode remeter a estados intensos, fortes, inauditos. Destramar o paradigma pode ser uma atividade ardente.

Hoje, lemos as fichas preparatórias desse curso como um belo livro fragmentário. Reafirmação do grau zero, o desejo de Neutro que o percorre nos deixa pensar que o sujeito que se proclamava "incerto" e "impuro"* - e que acreditávamos ser incerto e impuro -, na verdade, terá sido um sujeito surpreendentemente coerente. O Neutro seria a linha que nos leva ao insuspeito centro de Barthes.
•(Ibidem: I, 295.)

- (BACHELARD, Gastón. A formação do espírito científico. Tradução de Estela dos Santos Abreu. Lisboa: Dinalivro, 2006: 150-151.)

- (BARTHES, Roland. Essais critiques. OC: I, 325.)

(Ibidem: I, 361.)

(Ibidem: I, 546 e 573.)

- (BARTHES, Roland. Le Neutre: Cours au Collège de France 1977-1978. op. cit.: 32.)

- (BARTHES, Roland. Leçon. OC: $\mathrm{V}, 429$. 


\section{Leda Tenório da Motta}

Professora do Programa de Estudos Pós-Graduados em Comunicação e Semiótica da PUC/SP. Pesquisadora do CNPq, tradutora e crítica literária, com passagem pelos mais importantes cadernos de cultura. Tem sete livros publicados, entre eles Sobre a crítica literária brasileira no último meio século (Imago, 2002), Céu AcimaPara um tombeau de Haroldo de Campos (Perspectiva, 2005) e Proust - A violência sutil do riso (Perspectiva, 2007, na categoria Teoria \& Crítica Literária). Tem no prelo o volume Roland Barthes - O critico se ele ainda existe, em que estuda a trajetória deste que é hoje reconhecido como o mais instigante dos pensadores de sua geração.

Palavras-chave: Roland Barthes; Escritura; Grau Zero, Neutro.

Key words: Roland Barthes; writing; degree zero; neutral.

Mots-clés: Roland Barthes; écriture; degré zero; neutre.

\section{Resumo}

A mais de meio século da publicação de $O$ gran zero da escritura e a trinta anos do desaparecimento de Roland Barthes, ensaia-se aqui um exame da obra princeps, uma das mais radicais da crítica contemporânea e, bem por isso, uma das mais intrigantes. O presente artigo constitui-se de notas para um acercamento das principais influências ativas sobre o primeiro Barthes e das principais literaturas no horizonte desta nova crítica, quando ela principia, em 1953. Trata-se também de uma tentativa de pequena gênese do conceito de "grau zero", estranho ao corte saussuriano da escola das estruturas. Destas notas, espera-se que encaminhem um argumento em defesa da ideia de que, antes que erráticos, os escritos barthesianos são percorridos por uma linha de força representada pelo "grau zero", que nada mais é que o "neutro". A esse conceito sui generis - em sua última versão grafado com maiúscula - seria inteiramente dedicado o penúltimo curso no Collège de France. Podemos dizer que ele fecha um círculo virtuoso.

\section{Abstract}

The article focuses on Roland Barthes' first book Le degré zéro de l'écriture and its possible meanings half a century after the author's death. It also examines the philosophical and literary appropriations of the first Barthes and explores the hypothesis that his writings, once

\section{Résumé}

Un demi siècle après la publication de Le degré zéro de l'écriture, nous faisons ici un retour sur le premier livre de Roland Barthes. Il s'agit d'une tentative d'approche des principales influences, aussi bien philosophiques que littéraires, agissant sur cette œuvre inaugurale. Mais 
supposed fragmentary, appear to be coherent nowadays, thanks to the unbroken line that leads from the degree zero to the Neutral. ces quelques notes veulent aussi venir en appui à un argument en faveur de la profonde cohérence des écrits de Barthes, telle qu'il est possible de l'entrevoir dans la ligne sans partage qui mène du “degré zéro" au "Neutre". 